\title{
THE BROWN ROT FUNGUS IN PUERTO RICO ${ }^{1}$
}

\author{
JAIME R. GUISCAFRE \\ (With one plate and one figure in the text)
}

\section{INTRODUCTION}

Inasmuch as there are various causes of disease in Citrus in which a gum exudate in the trunk is a characteristic symptom; the term brown rot, as has been applied to the Phytophthora (Pythiacystis) type of gummosis has been selected as the most proper for the disease here reported. Mal-di-gomma or foot root rot also attacks the trunk and branches while other two forms of gummosis common in Porto Rico, grapefruit gummosis and psorosis of oranges, may exhibit similar symptoms.

The disease here reported was for the first time found on affected groves at the Eugenia plantation, near Añasco, while endeavoring to discover the possible causes of gum disease in Citrus. While maldi-gomma is very prevalent in that region, the Phytophthora rot plays no minor part in the havocs caused by the gum-type symptoms of disease. A preliminary report of this work has already been published by the writer and the present paper presents the results obtained in the studies of the disease.

The writer wishes to express his appreciation to Professor Rafael A. Toro, under whose direction the work was done, for suggestion of the problem, reading and correction of the proof and for invaluable aid and encouragement.

\section{SUSCEPTS}

\section{PLANTS AFFECTED}

Brown rot appears to be an important disease of the genus Citrus.

\section{VARIETAL SUSCEPTIBILITY}

The sour orange, (C. Aurantium) is the most resistant variety. In many cases the wounded tissues of orange trees have healed rapidly and the fungous growth being checked. The common lemon $(C$. Limonum) and the West India Lime (C. aurantifolia) are highly susceptible. The sweet orange (C. sinensis) and grapefruit (C. grandis) are between the highly susceptible $C$. aurantifolia and the very resis-

${ }^{1}$ Contribution from the Department of Botany, and Plant Pathology No. 1, College of Agriculture and Mechanic Arts, University of Porto Rico. Publication authorized by the Chancellor. 
tant species, C. Aurantium. No case has been reported of the disease occurring in the mandarin (C. nobilis) while, according to T. Fahmy, citron (C. Medica) is quite susceptible. Citron is the most common stock used in Egypt. The sweet lime (C. Limetta) was found to be susceptible in Palestine, where recently 20 per cent of Jaffa oranges, budded on sweet lime stock, were killed. The author also had the opportunity of observing a severe case of brown rot in the wild grapefruit tree (C. maxima) found in a coffee plantation at Mayagüez.

\section{The Disease}

\section{NAMES}

The disease is known by several names. Due to the fact that the causal fungus cause brown rot in lemons, it is generally called brown rot. It is also known as gummosis, but this is not a very appropriate term for the disease, since other several causes may contribute to this symptom.

\section{History AND RANGE}

In the early literature on citrus diseases there are many reports from different citrus-producing districts on the occurrence of gum exudates and gum diseases, but the forms reported are not accurately described; therefore, it is difficult to identify the causal agent.

The earliest serious outbreak of gummosis, occurred in the Azores Islands in the year 1834; although Ferrari in 1646 and Sterbeek in 1682 had already reported milder cases of the disease. Fouque (1873), referring to this destructive outbreak in the Azores Islands said that "sweet-orange trees 200 to 300 years of age which were producing 6,000 to 20,000 oranges a piece, were found to be affected by a serious form of gummosis. The trees put on heavy crops of fruits and the leaves turned yellow and fell off in great quantities".

Gum disease was reported from Italy between 1862 and 1878, by Savastano, Reggio and others. It was reported from the Balearic Islands (Spain) in 1871.. Very recently it was reported in the orient by Reinking (1921) and Lee (1925). In 1885 it was reported from New Zealand by Kirk and from Cape Colony, South Africa in 1891. Gummosis made its appearance in California in the year 1875 and in Florida in 1876. Garey states that gummosis was the most serious epidemy of 1878; for this reason common lemon, lime and citron stocks were no longer used, and the sour orange was unanimously adopted, due to its high resistance. Outside from the United States, it has been reported from Cuba by Cook (1906) and Cook and Horne 
(1908) ; from Brazil by Averna-Sacea (1917) ; from Mexico by Gándara (1910); from Paraguay by Bertoni (1911). It was not until 1918 that the disease was reported from Porto Rico by Stevenson.

Since the disease made its appearance, investigators from different localities, have stated their opinion as to the causative agent. Briosi (1878) who studied the disease in Italy, described a fungus Fusarium limoni, associated with gummosis; his description being very similar to that for Phytophthora citrophthora. In 1891, Comes from Italy, also produced gum by inoculation with a bacterial species called Bacterium gummosis. Swingle and Webber (1896) considered the gum disease as infectious and caused by organisms invading the bark. Fawcett and Burger (1911) and Fawcett (1912c, $1913 a)$ showed that a fungus similar to Diplodia natalensis produced gumming of branches.

Other investigators have concluded that gum diseases in Citrus are due not to organism, but to certain external stimulus against the affected region. Among these Sorauer (1872) in Germany and Prillieux (1874) in France, were the first to arrive at this conclusion, as a result of their work as to the cause of gum in the genus Prunus, the two genera being closely related. But Savastano, after working with both genera concluded that gummosis in Citrus is due largely to wounds or traumatisms. In recent years, Savastano has modified his earlier view recognizing that there is a gummosis formed as a result of the response of the tree to some external stimulus, and that there is another one caused by specific organism.

\section{IMPORTANCE}

Brown rot is a serious disease of citrus fruits. During the first months, the lesions are rather few and of relatively small area; in no way impairing the vigor of the tree. As the lesions extend into the branches of the trees, the folliage begins to be partially affected. In the last stages the lesions are so great that they really girdle the tree, causing the yellowing of leaves and finally defoliation. The lesions destroy the food-conducting vessels of the tree, affecting the leaves and fruits. The fruits remain undersize, ripen very late in the season, and the rind takes a dirty brown color.

The disease was so serious in California in 1878, that Garey (1882) referred to it as the only important disease at that time. When it appeared in the lemon trees in California, the industry was greatly injured, because not only was the orchard affected, but also the fruit spoiled after being packed. In the fruit the disease is called brown rot and it is readily transmitted by contact. The causal organism 
produces no spores in the firuit, but the disease is readily transmitted by pieces of mycelium of the fungus.

There is no accurate estimation of the economical importance of the disease in lemons in California, but during the first year, following its appearance, it caused great losses, both in the orchard and in the market.

Nobody has estimated the losses due to the disease in Porto Rico, but a visit to the Eugenia Grove, a few kilometers from the town of Anaseo, showed that the disease is of great importance. There are areas in which many trees are seriously affected; in others, however, young trees have been planted where the old ones died, and these trees are also affected, and producing fruits undesirable for the mar. ket. The fruit of affected trees is coarse, of dirty brown coloration, sour and insipid.

\section{SYMPTOMATOLOGY \\ MORPHOLOGIC SYMPTOMS}

The pathogene, generally affects the base of the trunk, and then works upwards, the lesions being always greater in length than in width. The bark is killed in patches accompanied by the exudation of gum, but the injury is not superficial, but rather cleep, the cambium being included always in the affected region. In other kinds of gummosis, such as Botrytis gummosis, the bark is softened. In brown rot gummosis, the bark remains hard until it is dry and then it cracks longitudinally. The exudation of gum, has been thought to be a physiological product of the reaction of the cells to protect the tree from rot-producing organisms. In resistant stocks, however, the lesions are self-limited, being a few inches long and wide, but on the susceptible species the author measured lesions of even 15 inches in length and 5-7 inches wide. As the disease progresses, the leaves on the side of the branches more seriously affected, begin to turn yellow, and finally die and fall. Superficially, the exudated gum is the most characteristical symptom of the disease. If the bark is removed, there is a more or less definite boundary between the sound and the infected area; this boundary being characterized by a light brown shaded area.

The bark at this time is yet firm, only the color is changed, from a pale normal green to a light brownish shade. The gum was observed to be formed near the cambium, in pockets 1 to 2 inches deep. The gum at the place of origin, is watery and elearer, while when coming through the bark, it becomes dark brownish red and denser. Later it turns dark brown, and becomes brittle due to the loss of 
water. The gum is deposited in oral masses, on the bark or follows the contour of the longitudinal eracks. In the last stages of the disease, the bark shrinks and cracks, leaving a surface covered with hardened gum, thus protecting to some extent the inner tissues from the invading rotting fungi. In the fruit the fungous causes a brown discoloration which gradually involves a great area of the rind. Sometimes gum exudates from the center of the spot.

\section{SIGNS}

Only in the laboratory are the characteristic signs of the disease showed.

\section{HISTOLOGIC SYMPTOMS}

Tissue from the bark was not examined for histological symptoms. Sections from rind of infected fruits of the Mexican Lime ( $C$. aurantifolia) were made and occasionally observed. The mycelium grows in thick masses in the lemon rind and is formed both intra and extracellularly. Disintegration of the cell wall was observed after few days of inoculation. A brown color was developed all around the place of inoculation.

\section{ETIOLOGY}

NAME HISTORY AND CLASSIFICATION OF IHE PATHOGENE

The organism was first isolated from diseased lemon trees, in California and named Pythiacystis citrophthora by Smith. Wilson unable to find any reproductive bodies suggested that the fungus be classified under sterile mycelium forms, while Leonian, after a physiological study of several species of the genus Phytophthora found that Pythiacystis citrophthora Sm. and Sm., was a Phytophthora and transfer the species to that genus. The organism is known to-day as Phytophthora citrophthora ( $\mathrm{Sm}$. \& Sm.) Leonian.

\section{PATPHOGENICITY}

Fawcett found that inoculation into sound trees with bits of diseased tissue transmitted the disease with all its characteristic symptoms; but, however, only diseased tissue from the marginal fringe of the killed bark of active lesions was capable of transmitting the disease. $\mathrm{He}$ also made inoculations with bits of lemon fruits affected with brown rot and produced the disease. The author, after isolating the fungus from diseased trees, inoculated ripen lemons, and the characteristic brown rot was produced. Reisolation proved the fungus causing it identical to that found in the diseased trees. 
The life history of the fungus is very simple.

When the soil is wet the mycelium is capable of producing sporangia and spores. If dry periods follow, the sporangia remained in a resting stage until favorable conditions return; however, during this time the fungus reproduces by means of pieces of its mycelium, and the disease is transmitted easily to the bark and fruits.

During wet seasons, the sporangia, which are produced in the soil, discharges biciliate motile spores which swim about, reach the bark, or fruit lying close to the ground and readily germinate, producing mycelium again. The organisms do not produce sporangia either in the bark or in the fruit. All attempts to find the sexual stage of the organism have failed. The author observed structures similar to what should be the sexual stage, but there were not convincely of their identity.

\section{Pathogenesis}

\section{INOCULATION}

The main sources of inoculation are the mycelium found in the soil, bark and fruits, and the spores which are only found in soil. Chlamydospores are also found on the soil and serve as inoculpn.

According to Fawcett, the period of inoculation of the fungus varies. With several inoculations he produced the characteristic disease after four months, in other instances, after six months. He recorded the death of a lemon tree after eighteen months from inoculation.

\section{SAPROGENESIS}

Phytophthora citrophthora lives saprophytically in the soil debris only and here produces spores and chlamydospores.

\section{INOCULATION}

The sporangia, chlamydospores and mycelium are carried by the water to different places of the orchard and the spattering rains, tools and animals will probably transport them and infect the sound trees.

\section{Characteristics of the Fungus}

Four different culture media were used to study the fungus. These were: corn-meal agar, corn-meal agar plus 5 per cent citric acid, moist clay soil and Cook II media. Sporangia could not be ] roduced in any of these media; even all trials with the moist clay 
soil failed to produce sporangia. The organism grew more luxuriantly at room temperature from $77^{\circ} \mathrm{F}$ average, in the corn-meal agar plus 5 per cent citric acid. Twenty-four hours after inoculation the fungus grew about $1 / 4$ inch, concentrically; at 48 hours was 1 inch; at 72 hours, 2 inches; at four days all the petri dish was covered with mycelium. Cultures after four weeks old turned to an ashy color. The mycelium is non-septate, profusely branched and cottony. In young cultures it is pure white, but as the culture becomes old it turns gray and ashy. The author examined the solid cultures daily and no sporangia were noticed from the first day of inoculation to six-week-old cultures, which were then left aside. The material was obtained from diseased trees in the Eugenia Grove, near the town of Añasco.

Material from different parts of the tree was tried in the following way: diseased tissue from the lesions and from 6 inches and one foot away from the lesion, respectively, were used. In no instance the tissue from itself produced the fungus, but only the material gathered from 6 inches and 1 foot away produced the characteristic mycelium.

After the writer failed to obtain sporangia from wet-soil cultures, a new method was developed. This method consisted in concentrating the corn-meal agar in the center of the petri dish forming a round mass of about 2 inches in diameter and $1 / 4$ inch thick, leaving a margin between this mass and the petri dish of $3 / 4$ inch. In this place, sterile water was poured. An inoculation was made with a bit of the mycelium in the center of the mass and from then on, the culture was examined daily. After 5 weeks, when the water became slimy, sporangia were abundantly produced. Continued examination showed that 6-7 weeks the sporangia became scarce while a flush of chlamydospores and conidia were conspicuously abundant. The sporangia observed were lemon-shaped, in some cases elongated while in others more rounded with a protuberance at the tip. Intercalary sporangia were found in some oceasions and sporangia with two pores were observed. They showed $\mathrm{a}$ wide rănge in size and shape, but in the average they were $8 \mathrm{u}$ long and $6 \mathrm{u}$ wide. The chlamydospores range from well-rounded ones to elongated and averaged $6 \mathrm{u}$ in diameter. Spores were seen germinating and they were of approximately the same size as the chlamydospores. The sporangiophores were rather short: $2 \mathrm{u}$ in length, but there were some which attained 16 and $18 \mathrm{u}$.

In the first attempts to isolate, the organism always an infection of a Fusarium species was present; according to Fawcett the secondary infection of the Fusarium species slightly increases the injury of 
$P$. citrophthora. The only way of getting rid of this secondary infection was by inoculating healthy lemon fruits with the mixed culture after which $P$. citrophthora remained alone in the inoculated lemons, isolating from this the fungus in pure cultures.

\section{EPIPITTOLOGY}

Gummosis caused by $P$. citrophthora needs several factors in order to develop in an orchard. The factor of prime importance is moisture, the secondary ones being: injuries, favorable temperature and the resistance or susceptibility of the stock used. The injuries of any nature are not essential for the rapid development of the disease; whenever moisture and favorable temperature prevail, the fungus enters the bark easily.

Moisture is the essential factor for spreading the disease. For example, in the Eugenia Grove, the trees are budded low, it rains abundantly, from 70 to 80 inches amnually and the water table is often found at 1 to $11 / 2$ foot below the surface. This is a favorable place for the development of the disease.

\section{CONTROL}

\section{PREVENTION}

In all diseases, the methods for prevention are the cheapest and most easily carried out, but they are often neglected by the growers. There has been formulated some very good methods for the prevention of gummosis. These are: (1) plant the trees in mounds, in this way the tree will have its roots well exposed and, therefore, afford less chance for the development of the disease; (2) by avoiding injuries of any sort to the bark or crown roots; (3) providing a good drainage system, and, finally, (4) used, where possible, resistant stocks such as sour 'oranges.

Other methods are: paint the basal part with Bordeaux paste, and, in places where irrigation water is used, dig the soil among the main roots and leave a circular ridge around the tree.

Another method which has proved very successful is tree surgery. This consists in scraping the bark slightly to see the extent of the infection. Then the "invaded area", or brownish zones, is dessected out with a heavy lnife cutting thru the wood about $1 / 2$ to 1 inch beyond the invaded zone on the sides and from 1 to 2 inches beyond both at top and bottom. The cut above and below are made at an acute angle. Then the wound is desinfeeted by any of the commercial desinfectants such as Bordeaux paste, using 1 pound copper sul- 
fate and 2 pounds rock lime to $1 \frac{112}{2}$ gallons of water. Protexol may be used also. After this treatment, the purpose of which is to kill spores or mycelium present, the wound is painted.

College of Agriculture and Mechanic Arts, University of Porto Rico, Río Piedras, P. R.

\section{Fxplanation of Plates}

PLATE XVII

Grapefruit trees at Hacienda Eugenia showing effects of Phytophthora citriphora infection.

\section{PLATE XVIII}

A.-The mycelium showing its non-septate condition and its habitual way of branching.

B.-Usual type of sporangia at several stages of development.

C.-Sporangia and chlamydospores showing their characteristic forms and shapes.

\section{Literature Cited}

1. Averna-Saccá, Rosario, Malestias de Laranjeria. Bol. Agr. Sao Paulo, ser. $18: 33 \pm-346.1917$.

2. Bertoni, Moisés S., Contribución al Estudio de la Gomosis del Naranjo, Agronomía, Paraguay 5:77-89. 1911.

3. Curativo y Preventivo. An. Cient. Paraguayos, ser. 2 : 408-421. 1919.

4. Cook, Mel. T., Gomosis. Primer Informe Anual. Est. Cent. Agron. Cuba. 1904-05. 1906.

5. . the Orange. Est. Cent. Agron. Cuba. Bul. 9:40. 1908.

6. Fawcett, H. S., Gummosis of Citrus Trees. Fla. Agr. Expt. Sta. Press Bull. 134. 1909.

7. _..................... Diplodia natalensis as a Gum Indueing and Fruit Rotting Fungus. Fla. Agr. Expt. Sta. Ann. Rept. 11: 61-67. 1910 .

8. -......... Gumming. Florida Agr. Expt. Sta. Ann. Rept. 1911-12 12:77-92.

9. Known Trees in California. Mo. Bull. State Con. Hort. Cal. 2:601. 1913 .

10. - Known Distribution of P. eitrophthora and its Probable Relation to Mal-di-gomma of Citrus. Phytopathology $5: 66-67.1915$.

11. - Pythiacystis and Phytophthora. Phytopathology 10:397-399. 1920 . 
THE JOURNAL OF THE DEPARTMENT OF AGRICULTURE OF P. R.

12. 24: 191-236. 1923.

13. Ferrari, G. B. Hesperides; Live, de Malorum Aureorum Cultura and USA Libri Quatour. 480: 1646.

14. Fouqué, F., Voyages Geologiques aux Açores III. Les Cultures de San Miguel. Rev. Deux Mondes, tome 104:82.9-863. 1873.

15. Gándara. Guillermo, Enfermedades y Plagas del Naranjo. Est. Agron. Cent. Mexico Bol. 31. 1910.

16. Garey, Thomas A., Orange Culture in California, 227. San Francisco 1882.

17. Grossenbacher, J. G., Some Bark Diseases of Citrus Trees in Florida. Phytopathology 6:29-50. 1916.

18. Guiscafré, J. R., Gomosis de la Toronja en la Hacienda Eugenia, Pto. Rico. Rev. Obras Púb. Puerto Rico 85:124-125. 1931.

19. Kirk, Thomas. Diseases of Lemon and Other Trees in New Zea. land. $5 \mathrm{pg}$. Wellington 1885.

20. Klotz L. S., and H. S. Fawcett, The Relative Resistance of Varieties and Species of Citrus to Pythiacystis Gummosis and other Bark Diseases. Journ. Agr. Res. 41:415. 1930.

21. Lee, H. A., Further Data on the Susceptibility of Rutaceous Plants to Citrus Canker. Journ. Agr. Res. 15:661-666. 1918.

22. Leonian, Leon H., Physiological Studies on the Genus Phytophthora. Amer. Journ. of Botany 12:444-498. 1925.

23. Nowell, W., Diseases of Lime and Other Citrus Trees. Diseases of Crop Plants in the Lesser Antilles 194-224.

24. Prillieux, Ed., Etude Sur la Formation de la Gomme dons les Arbres Fruitiers. Compt. Rend. Acad. Paris. 78:135. 1874.

25. Savastano, Liugi Salvatore, Gommose Caulinaire et Radicale dans les Aurantiacées, Amygdalés, Le Figuier, L'Olivier, et Moircissement du Noyer. Compt. Rend. Acad. Sci. Paris 99: 987-990. 1884.

26. Smith, Ralph E., The Brown Rot of Lemons. California College of Agric. Exp. Sta. Bull. 190. 1907.

27. -_._._- and 0 . Butler, Gum Disease of Citrus Trees in California. California College of Agric. Expt. Sta. Bull. 200. 1908 .

28. Sterbeeck, F. V., Citruculture oft Regeringue der Uythemsche Boomer Te Weter Oravier, Citroenen Limoenen, Gavater, Laurieren en Andere. 296 pg. Antweys 1682.

29. Stevens, H. F., Florida Citrus Diseases. Fla. Agr. Expt. Sta. Bull. 150. 1918.

30. Stevenson, John A., Citrus Diseases of Porto Rico. Journ. Dept. of Agric. Porto Rico 2:43-123. 1918.

31. Soraeur, Paul, Einige Beobachtungen, Uber Gumminildung. Landw. Vers. Sta. 15: 454-465. 1872.

32. Swingle, Walter T., Citrus. Bailey L. H. Stand. Cyclopedia of Hort. 2:780. 1914. 


\section{PLATE XVII}
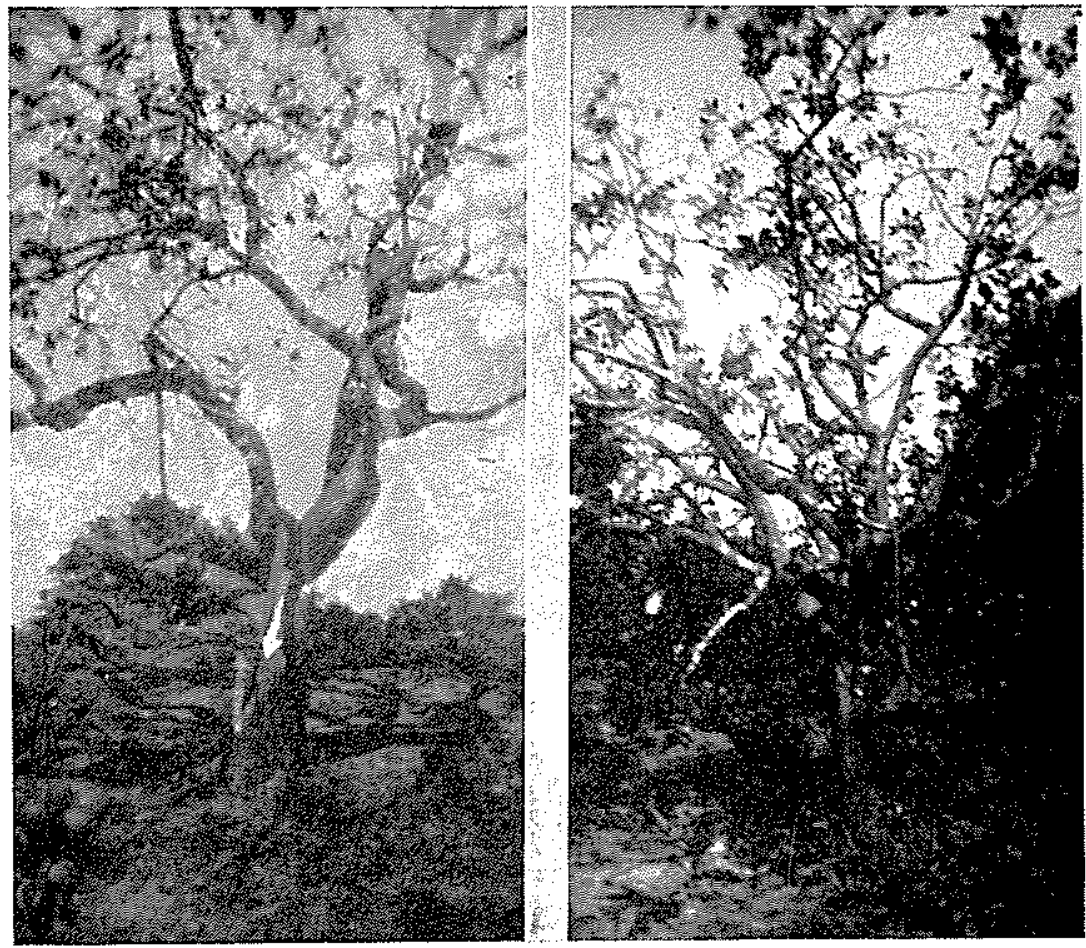


\section{PLATE XVIII}

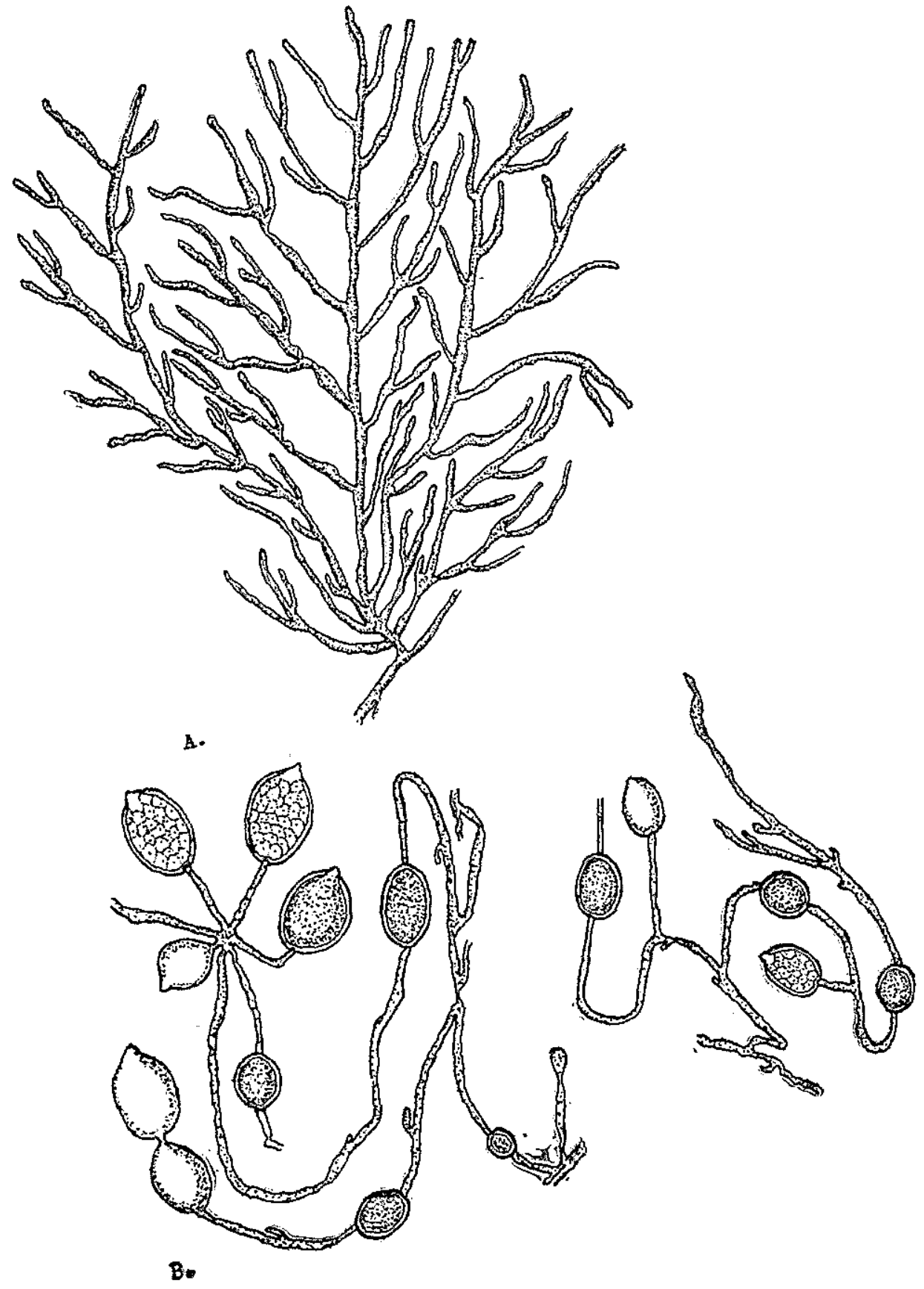

